\title{
ASESMEN KETERAMPILAN MAHASISWA BIMBINGAN DAN KONSELING SEMESTER ENAM DALAM PELAKSANAAN KONSELING LINTAS BUDAYA
}

\author{
Muhammad Ferdiansyah $^{1}$ dan Romadhona Noverina ${ }^{2}$ \\ Prodi Bimbingan Konseling Universitas PGRI Palembang \\ Email: $\underline{\text { mferdiansyah34@yahoo.com }}{ }^{1} \underline{\text { romadonanoverina@gmail.com }}^{2}$
}

\begin{abstract}
ABSTRAK
Indonesia merupakan negara yang sangat kaya akan perbedaan masyarakat, sehingga dalam pelaksanaan konseling konselor berpotensi mengalami kegagalan dalam memahami budaya peserta didik atau konseli sehingga dapat berakibat pada gagalnya proses konseling. Penelitian ini bertujuan untuk mendapatkan hasil asesmen dan kemudian diajadikan sebagai informasi untuk mengambil tindakan yang lebih baik. penelitian menggunakan metode evaluasi dengan pendekatan studi kasus. Teknik pengumpulan data dengan wawancara, observasi, dokumentasi dan FGD. Penentuan informan menggunakan teknik purposive sampling. Temuan penelitian diperiksa melalui empat kreteria yaitu (1) uji Kepercayaan 2) Keteralihan, 3) Defendibilitas 4) Konformitas. Hasil penelitian ditemukan bahwa; a) kesalahan dalam melakukan diagnosis masalah konseli b) lemahnya wawasan tentang budaya konseli c) Lemahnya kemampuan dalam membangun relasi terapeutik, d) kesulitan dalam melakukan empati dan e) lemah dalam mengeksplorasi masalah konseli
\end{abstract}

Kata Kunci: Asesmen, Keterampilan Mahasiswa BK, Konseling Lintas Budaya.

\begin{abstract}
Indonesia was a country that has many various in community differences, so that in the implementation of counseling, counselor had the potential to fail in understanding the culture of students or counselees, so it can be resulted in the failure of the counseling process. This study was aimed to obtain assessment result then made as information to take better action. The research used evaluation methods with a study case approach. The technique of collecting data was used by interview, observation, and documentation. The sample was used purposive sampling technique. The research findings were examined through four criteria, namely (1) Trust test, 2) Transferability, 3) Dependability, 4) Conformity. The result was showed that students were not skilled in a) diagnosing counselee problems b) low of insights about counselee culture c) low of ability to build therapeutic relationship, d) difficulty in doing empathy and e) low in exploiting counselee problems.
\end{abstract}

\section{Keywords: Assessment, Counseling Guidance Student Skills, Cross-Cultural Counseling.}




\section{PENDAHULUAN}

Indonesia merupakan negara majemuk dengan populasi manusia terbesar ke empat didunia dengan jumlah penduduk 265 juta jiwa The Spectator Index (Okezone.com Juli 2018). Potret kebudayaan yang terdapat di Indonesia sangat beragam dan juga bervariasi, tidak kalah pentingnya juga secara sosial dan politik, Indonesia mempunyai jalinan sejarah serta dinamika interaksi diantara kebudayaan yang satu dengan kebudayaan yang lain secara kuat. Keragaman budaya merupakan kekayaan di Indonesia yang dapat merekatkan dan juga sebaliknya, tidak dipungkiri potensi perpecahan akibat perbedaan ini suatu saat juga masih dapat berpotensi kearah pertikaian, oleh karena itu para konselor di lingkup apapun harus paham kalau mereka sedang berda pada masyarakat yang majemuk, konselor harus juga harus menyadari tengah menghadapi beragam manusia.

Dalam konseling lintas budaya, tujuan yang hendak dicapai tidak boleh terhalang oleh perbedaan budaya konselor dan konseli. Tentunya hal ini merujuk pada landasan filosofis yang sering dinyatakan sebagai sebuah martabat yang melekat pada individu, penghargaan atas keindividualan, hak individu bagi aktualisasi diri dan lain-lain, mengindikasikan komitmen konselor bagi konseling yang efektif untuk semua konseli apapun latarbelakang budaya, etnik religius atau sosial-ekonominya. Meskipun demikian, yang sama pentingnya dengan komitmen tersebut adalah konselor harus bergerak menuju pengejaran aktif fondasi teoritis yang tepat, dan praktik-praktik yang efektif, kalau ingin berhasil melakukan konseling dari latar belakang budaya yang berbeda-beda (Iswari M, 2013:9)

Program studi Bimbingan dan Konseling (selanjutnya disingkat BK) FKIP Universitas PGRI Palembang, sebagai satu-satunya lembaga Pendidikan Tinggi Swasta (PTS) sebagai penyelengara Prodi BK di Sumatera Selatan yang menjadi wadah dalam menyiapkan calon tenaga guru BK profesional, harus berperan aktif dalam meningkatkan kualitas lulusannya. Ferdiansyah M, (2018; 45) mejelaskan seiring dengan perkembangan, mahasiswa BK perlu dibekali seperangkat wawasan, pengetahuan, keterampilan dan sikap untuk merespon percepatan kemajuan zaman tersebut. Untuk mencapai hal tersebut, dosen sebagai salah satu komponen penting dalam sebuah lembaga pendidikan yang betugas 
mentransformasikan ilmu pengetahuan di program studi BK harus mampu membekali mahasiswa dengan strategi atau metode baru dalam bidang BK. Untuk itu materi yang akan diajarkan tentu saja harus memiliki standar dan tujuan pencapain yang jelas. Agar dapat menghasilkan lulusan yang berkualitas.

Merujuk pada penjelasan tersebut, disadari bahwa bahwa program studi BK FKIP Universitas PGRI Palembang saat ini masih belum maksimal dalam menghasilkan lulusan yang dapat membantu penyelengaraan BK secara profesional di sekolah khususnya di Sumatera Selatan. Hal ini diperkuat dengan penelitian yang dilakukan oleh Ferdiansyah, M \& Efrianto (2018:43) menemukan bahwa pola guru BK dalam (alumni Universitas PGRI Palembang) dalam penganan siswa bermasalah masih dominan menggunakan pendekatan disiplin. Berdasarkan temuan penelitian tersebut tentu saja berbagai upaya perbaikan sedang diupayakan oleh program studi BK dalam memaksimalkan kualitas mahasiswa dan lulusan agar mampu berkontribusi besar dalam perbaikan kualitas pelayanan konseling di sekolah.

Konseling merupakan layanan bantuan yang diberikan oleh tenaga profesional kepada seorang atau sekelompok individu untuk pengembangan kehidupan efektif sehari-hari dan penanganan kehidupan efektif sehari-hari yang terganggu dengan fokus pribadi mandiri yang mampu mengendalikan diri melalui penyelenggaraan berbagai jenis layanan dan kegiatan pendukung dalam proses pembelajaran (Prayitno, 2013). Berdasarkan point profesional yang dimaksud dapat dipahami bahwa seseorang yang dapat dikatakan profesional dalam pengertian yang lebih luas adalah orang yang memiliki keahlian khusus yang diperoleh melalui pendidikan dan dapat mempraktekkannya secara terampil, tidak asal jadi.

Mahasiswa BK sebagai calon tenaga profesional dalam bidang konseling harus paham, jika perbedaan bahasa dan dialek antara mereka dan konseli berpengaruh besar bagi kesuksesan konseling, meskipun perbedaan budaya di generasi belakangan semakin diakui sebagai daya penggerak terbesar bagi terjalinnya hubungan antar manusia, namun tidak bisa membiarkan hal itu menyamarkan kebutuhan muntlak konselor untuk memahami antara budaya mereka sendiri dan budaya konselinya. 
Lebih jauh lagi untuk memulai perjalanan menuju menjadi seorang konselor yang kompeten secara budaya, mahasiswa harus terlebih dahulu bertanya pada diri sendiri, "bagaimanakah pemahaman saya dalam melakukan konseling lintas budaya? Ada banyak aspek budaya dan banyak dari mereka, seperti bahasa, kebiasaan, nilai-nilai, keyakinan, spiritualitas, peran jenis kelamin, riwayat sosial politik, dan sebagainya, mungkin memiliki dampak dalam konseling. Sehubungan dengan itu Karya Dyche dan Zayas (1995) menunjukkan bahwa sebagian besar praktik konseling multikultural didorong oleh rangkaian prinsip atau keyakinan, bukan dilandasi oleh rangkaian teknik atau ketrampilan khusus. Konselor multikultural dapat menggunakan bentuk penyampaian yang beragam, mulai dari individual, pasangan, keluarga atau kelompok, dan memanfaatkan intervensi tertentu seperti pelatihan relaksasi, analisis mimpi, atau refleksi empatik.

Sehubungan dengan itu Sumatera selatan merupakan provinsi dengan kondisi demografi yang beragam, ditinjau dari segi suku. Provinsi Sumatera Selatan memiliki banyak suku asli diantaranya suku Gumai, suku Ogan, suku Lematang, suku Palembang, suku Komering dan lain-lain, masing-masing suku tersebut memiliki karakteristik yang berbeda baik dari, bahasa, adat istiadat, kepercayaan dan kebiasaan sehari hari, oleh karena itu dalam pelaksanaan proses konseling konselor hendaknya memiliki wawasan yang luas, agar dapat mengunakan berbagai pendekatan emik dan etik dalam proses konseling.

Selanjutnya kompetensi konselor lintas budaya harus fokus terhadap keterampilan penting yang dimiliki oleh konselor diantaranya adalah: (1) Sikap dan keyakinan yang tepat dalam arti bahwa mereka menyadari asumsi, nilai - nilai dan bias, (2) Pengetahuan yang dibutuhkan tentang budaya klien mereka sehingga mereka dapat lebih memahami kliennya, (3) repertoar keterampilan atau alat yang dapat secara efektif diterapkan pada klien dari berbagai latar belakang (Arredondo, 1999; Sue \& Sue, 2008 dalam Neukrug, 2012 : 487). Mencermati hal tersebut maka peneliti menyadari, bahwa pentinggya keterampilan konseling lintas budaya dalam proses keberhasilan konseling, maka penelitian ini perlu dilakukan di program studi bimbingan dan konseling FKIP Universitas PGRI Palembang. 


\section{METODE PENELITIAN}

Penelitian ini menggunakan desain penelitian evaluasi kualitatif dengan model studi kasus. Menurut Yusuf (2013:53) penelitian evaluatif adalah penelitian yang bertujuan untuk menilai sesuatu yang sedang berlangsung, dalam hal ini peneliti akan melakukan evaluasi proses pembelajaran keterampilan pelaksanaan konseling lintas budaya yang sedang dilaksanakan di semester enam, untuk mendapatkan data yang tepat peneliti mengunakan teknik purposive sampel dalam penentuan informan. Informan penelitian merupakan orang yang dimanfaatkan untuk memberikan informasi tentang situasi dan kondisi latar penelitian (Moleong, 1998: 90). Temuan penelitian selanjutnya diuji keabsahan melalui empat kreteria yaitu (1) uji Kepercayaan (2) uji Keteralihan, (3) uji Defendibilitas (4) uji Konformitas (Ferdiansyah 2015:66). Selanjutnya Yin, (2008: 140) menjelaskan agar temuan di lapangan dapat disusun secara sistematis, maka strategi analisis yang dapat digunakan adalah analisis dominan, analisis dominan tersebut terdiri dari tiga sub kegiatan yaitu penjodohan pola, penjelasan, analisis derat waktu.

\section{HASIL DAN PEMBAHASAN}

Berdasarkan data dan fakta selama di lapangan, ditemui berbagai fenomena yang diharapkan dapat menjadi bahan perbaikan bagi Program Studi BK Fakultas Keguruan dan Ilmu Pendidikan Universitas PGRI Palembang dalam upaya memperbaiki pola perkuliahan. Agar dapat dipahami berikut peneliti jelaskan berasarkan fokus dan tujuan penelitian. Setelah peneliti melakukan kegiatan pengumpulan data melalui wawancara, pengamatan, studi dokumentasi.

Berdasarkan hasil pengamatan wawancara dan studi dokumentasi, diperoleh data bahwa pada pada praktek pelaksanaan konseling lintas budaya mahasiswa mengalami beberap kendala yang cukup beragam, sebagaimana yang dikemukakan oleh "MD" sebagai berikut:

Saya belum memiliki perasaan yang peka terhadap apa yang didinginkan oleh konseli, apalagi untuk konseling yang berbeda pandangan dalam memandang sesuatu dengan saya, misal saat saya melakukan konseling dengan masyarakat yang memiliki keyakinan yang kuat terhadap hal-hal yang bebrbau magis yang cenderung mengarah pada hal irrasional saya 
kesulitan melakukan konseling dengan pendekatan budaya. (Wawancara, Selasa 3 Februari 2019)

Dari penuturan di atas peneliti mendapatkan keterangan bahwa pada saat melalakukan konseling dengan konseli yang memililliki pandangan budaya yang berbeda mahasiswa cenderung keliru melakuakna diagnosis masalah dan menafsirkan apa yang menjadi permasalahan konseli. Bukan itu saja peneliti juga mendapatkan data memalui pengamatan saat mahasiswa semester enam melakukan praktek konseling lintas budaya, mahasiswa belum terampil dalam mengekspolari permasahan yang dialami oleh klien, lemahnya keterampilan dalam membuat pertanyaan terbuka dan cenderung terjebak persepsi stereotip tentang konseli menyebabkan pelaksanaan konseling terlihat tidak berkembang.

Apa yang dialami oleh mahasiswa semester enam terebut senada dengan Scheutz (dalam Lago 2006 : 49) menunjukan bahwa "semua pengetahuan dan praktik budaya yang koheren hanya sebagian yang jelas dan sama sekali tidak bebas dari kontradiksi (perlawanan/perbedaan). Pernyataan ini memiliki 2 implikasi yaitu (1) ketika kita melihat budaya orang lain kita memiliki (mungkin ketidaknyamanan) pengalaman dalam memahami fenomena yang tidak semua jelas secara langsung. (2) ketika kita meneliti diri sendiri, kita tidak mungkin menghargai inkoherens dan kontradiksi yang ada kecuali kita dibantu oleh pihak luar. Oleh karena itu perlu usaha yang dilakukan dalam gerakan konseling multikultural untuk mencari cara memfasilitasi perkembangan kesadaran, pengetahuan, dan ketrampilan kultural yang sesuai.

Untuk itu seorang mahasiswa sebagai calon konselor lintas budaya yang efektif hendaknya memiliki kesadaran latar belakang budaya sendiri dan telah secara aktif mendapatkan kesadaran lebih lanjut tentang bias sendiri, stereotip, dan nilai-nilai. Meskipun konselor lintas budaya yang efektif tidak dapat memegang sistem kepercayaan yang sama dengan kliennya, ia dapat menerima berbeda pandangan dunia yang disajikan oleh penolong. Dengan kata lain, "Perbedaan tidak dilihat sebagai penyimpangan". Menjadi peka terhadap perbedaan dan menyiarkan bias budaya sendiri memungkinkan konselor lintas budaya yang efektif untuk merujuk konseli dari kelompok nondominan kepada konselor budaya konseli sendiri ketika rujukan akan menguntungkan penolong 
tersebut. Sayangnya, contoh profesional kesehatan mental yang telah gagal secara budaya berbeda dari diri mereka sendiri sebagai akibat dari bias dan prasangka mereka sendiri yang umum (Sue \& Sue, 2008).

Mahasiswa selaku calon konselor lintas budaya idealnya mampu menerapkan, menyesuaikan, generik wawancara dan keterampilan konseling dan juga memiliki pengetahuan serta memiliki keterampilan khusus dan intervensi yang mungkin efektif dengan klien dari beragam kelompok budaya. Mahasiswa BK hendaknya juga memiliki pengetahuan dan memahami bahasa verbal dan nonverbal klien dan dapat berkomunikasi secara efektif.

Selain itu, seorang mahasiswa BK idealnya terampil menghargai pentingnya memiliki perspektif sistemik, mengenai pemahaman tentang dampak keluarga dan masyarakat pada konseli, mampu bekerja sama dengan tokoh masyarakat, teman sejawat, dan profesional lainnya. Apa yang terjadi ketika mahasiswa BK tidak memiliki keterampilan yang sesuai ketika bekerja dengan siswa beragam budaya? Kemungkinan besar, siswa yang akan menjadi konseli akan merasa putus asa dan tidak puas terhadap layanan konseling.

\section{PENUTUP}

\section{Kesimpulan}

1. Konseling lintas budaya melibatkan konselor dan konseli yang melibatkankan latar belakang budaya yang berbeda, oleh karena itu proses konseling rawan akan terjadinya bias budaya dari pihak koselor yang dapat menghambat proses konseling

2. Perlunya mahasiswa BK sebagai calon konselor memiliki kepekaan budaya untuk dapat memahami dan membantu konseli, hal ini agar mahasiswa BK sebagai calon konselor menghargai dimensi keindividualan yang melekat pada individu konseli

3. Pengetahuan, sikap dan keterampilan intervensi dalam hubungan konseling lintas budaya sangat menentukan keberhasilan proses konseling lintas budaya 


\section{Saran}

Berdasarkan temuan penelitian tersebut maka peneliti menyarankan kepada perangkat/personil penyelengara program studi untuk memiliki komitmen yang kuat dalam menyelengarakan proses perkuliahan, utamanya pada matakuliah praktek keahlian, sehingga penyelengaraan pendidikan sekarang ditingkatkan kembali dalam rangka menghasilkan mahasiswa dan lulusan yang berkualitas dan berkontribusi besar bagi penyelengaraan pelayanan konseling di sekolah.

\section{DAFTAR PUSTAKA}

Ferdiansyah, M \& EFrianto. (2018). Pola Guru Bimbingan dan Konseling dalam Penanganan Siswa Bermasalah di SMA PGRI 4 Palembang.. Journal of Innovative Counseling: Theory, Practice \& Research, 1 (1): pp. 91-94.

Ferdiansyah, M. (2015). Dasar Penelitian Kualitatif. Bogor: Herya Media.

Iswari Mega, 2013. Efefective of Counseling Process With Understanding Communication Bettwen Culture. Prosiding Seminar Internasional Konseling. Bali: Undiksha.

Lago. Collin (2006). Race, Culture and Counselling The Ongoing Challenge. England: McGraw-Hill House.

Moleong. (1998). Metodelogi Penelitian Kualitatif. Bandung: PT. Remaja Rosdakarya.

Neukrug Edward S., 2012. Theory, Practice, and Trends in Human Services.USA: Cangage-Global.

Prayitno, 2012. Wawasan Profesional Bimbimbingan dan Konseling. Padang: UNP Press.

Yin. Robert. K (2018). Studi Kasus. Desain dan Metode. Terjemahan oleh M. Zauzi Muzakir. Jakarta: PT Raja Grafindo.

Yusuf. A. Muri (2013). Metode Penelitian; Kuantitatif, Kualitatif dan Penelitian Gabungan. Padang: UNP Preess. 